\title{
Influence of Plantation Establishment on Discharge Characteristics in a Small Catchment of Tropical Forest
}

\author{
Siti Aisah Shamsuddin, ${ }^{1}$ Zulkifli Yusop, ${ }^{2}$ and Shoji Noguchi ${ }^{3}$ \\ ${ }^{1}$ Forest Research Institute Malaysia, 52109 Kepong, Selangor, Malaysia \\ ${ }^{2}$ Institute of Environmental and Water Resource Management, University Technology Malaysia, 81310 Skudai, Johor, Malaysia \\ ${ }^{3}$ Department of Soil and Water Conservation, Forestry and Forest Products Research Institute, Tsukuba, Ibaraki 305-8687, Japan \\ Correspondence should be addressed to Siti Aisah Shamsuddin; sitiaisah@frim.gov.my
}

Received 29 August 2014; Revised 18 November 2014; Accepted 18 November 2014; Published 16 December 2014

Academic Editor: Piermaria Corona

Copyright (C) 2014 Siti Aisah Shamsuddin et al. This is an open access article distributed under the Creative Commons Attribution License, which permits unrestricted use, distribution, and reproduction in any medium, provided the original work is properly cited.

A study was conducted on the impact of forest clearance on discharge from newly established Hopea odorata plantations catchment (14.4 ha). The stands were two years old when this study commenced in year 2006 and the data collection was carried out for two years. The forested catchment (C3) was clear-cut during the preparation of the forest plantation and catchment $\mathrm{C} 1 \mathrm{was}$ left undisturbed. Discharge and rainfall were measured continuously for two years. The discharge measured from years 1997 to 2003 was used also to determine the water yield before and after forest clear-cut. This study showed that the plantation catchment is more responsive to storm with higher total water yield than in the forested catchment. The effect of forest clear cutting to discharge was clearly shown by the increment in the amount following the clear-cut activities and time taken for the recovery of the discharge back to its original state was almost three years. The peak discharge in $\mathrm{C} 3$ also was affected in which the biggest change was obtained during the forest clear-cutting period compared with during calibration and after clearing periods. This study is useful as basis for improving the existing guidelines on forest plantation establishment.

\section{Introduction}

The effects of deforestation on catchment hydrology are dependent on the removal of dominant plant species and the climate [1]. In catchments that receive high rainfall and have tall vegetation, streamflow is a useful indicator of hydrological responses to land-use change [2]. Increase in water yield would be expected following deforestation or removal of forest cover. The magnitude of increase varies with the annual rainfall and the proportion of cover removed [1].

In Malaysia, the main conversion of forest is from lowland forest to agriculture, especially rubber and oil palm plantations, which started in the early 1960s. The study on hydrological parameters by Abdul Rahim [3] on the conversion of secondary dipterocarp forest to cocoa and oil palm plantations at Sungai Tekam, Pahang, revealed that the highest increases in water yield occurred in the second and fourth years after treatment with $157 \%$ and $470 \%$ of increments, respectively $\left(P=1878 \mathrm{~mm} \mathrm{yr}^{-1}\right)$. The forested catchment had been subjected to timber logging, clear felled, burning of logs, road construction, and tree plantings. Another study carried out by Abdul Rahim and Harding [4] at Berembun Watershed, Negeri Sembilan, showed the effects of selective logging (commercial and supervised) on water yield and streamflow. They found significant water yield increases in both catchments of which $70 \%$ was from commercial logging and 37\% was from supervised logging following the treatments, and the increases continued until the fourth year $\left(P=2126 \mathrm{~mm} \mathrm{yr}^{-1}\right)$. However, a small increase in the water yield was observed in the study at Sipitang, Sabah by Malmer [5] when logged over forest was converted to A. mangium plantation involving manual felling, manual wood extraction and no burning was applied. Annual water yields increases were observed from 80 to $197 \mathrm{~mm}$ for 3 years of study duration $\left(P=3341 \mathrm{~mm} \mathrm{yr}^{-1}\right)$. The study also included the conversion of secondary vegetation to $A$. mangium plantation which 
applied the normal practices and the results showed that the water yield was increased higher than the manual felling with 89-522 $\mathrm{mm}$ with the same time duration.

The impact of forest harvesting, thinning, and other silvicultural treatments on runoff has been carried out by scientists using paired catchment experiments in which the catchment size is less than $100 \mathrm{~km}^{2}$ and the results have shown that forest harvesting can significantly increase annual runoff and magnify peak flow [6-13].

Forest plantation will be the future source of timber to meet the forest resources demand and also because logging in upper hill forest will be more costly. However, there is no examination on the effect of establishment of forest plantation on runoff characteristics in Malaysia.

The purpose of this study was to analyse the hydrograph characteristics of a young forest plantation (C3), Hopea odorata, in comparison with a forested catchment (C1). From the hydrograph, water discharges $(Q)$ were determined using equations which were obtained from rating table curves of each catchment, followed by the hydrograph separation processes in order to separate the stormflow from the baseflow before further analysis can be carried out. The studies focused on four aspects; that is, first, in the water yield aspect, we use the unpublished daily discharges data from years 1997 to 2004, 2006, and 2007 in the analysis of water balance with the objective to look at the changes over the selected years. In the other two aspects, we used the 2006 and 2007 data observation only for hydrograph analysis of stormflow and stormflow response to rainfall characteristics. The stormflow analysis is to determine the relationships between the stormflow and rainfall for both catchments while stormflow response to rainfall is to examine the hydrograph characteristics differences between the two catchments related to wet and dry conditions of the soil. The last aspect is the analysis on peak discharges before and after the forest clearance from 1997 to 2007. The regression analysis on dummy variables was applied on peak discharges to determine the effect of forest clearance on $Q$.

\section{Material and Methods}

2.1. Study Area. This study was conducted in catchment C1 (32.8 ha) and catchment C3 (14.4 ha) at Bukit Tarek Experimental Watershed $\left(3^{\circ} 31^{\prime} 30^{\prime \prime} \mathrm{N}, 101^{\circ} 35^{\prime} \mathrm{E}, 48-213 \mathrm{~m}\right.$; Figure 1), Peninsular Malaysia. This forest is classified as a lowland rainforest and was first logged in 1963. The catchment characteristics of $\mathrm{C} 1$ and $\mathrm{C} 3$ are shown in Table 1. The original composition of vegetation was dominated by Koompassia malaccensis, Eugenia spp., and Canarium spp. The period between January 1997 and October 1999 was taken as a calibration period. The commercial timber trees in C3 were logged from November 1999 until August 2000. The remaining unmerchantable trees were clear-cut and the residual trees were burnt from December 2003 to January 2004 prior to forest planting. The Hopea odorata trees were planted in April 2004. The trees were about two years old when this study was initiated. The period of data observed

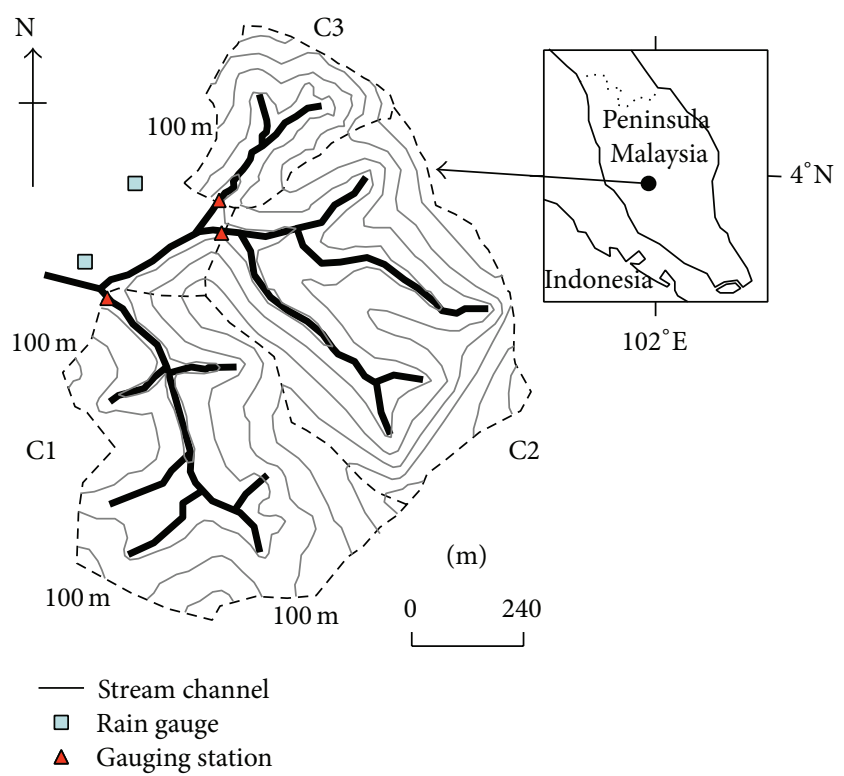

FIgURE 1: Bukit Tarek Experimental Watershed, Kerling, Selangor.

from September 2000 to December 2003 was considered as the period after forest logging.

This area is dominated by metamorphic rock from Arenaceous series with silt sediment which was formed in Triassic Era [15]. Some slopes in these catchments can reach up to $40^{\circ}$ as a result of metamorphic process in this area with strong forces from both W-SW directions $[16,17]$.

2.2. Hydrological Observation. Runoff discharge was measured at the 120-degree $\mathrm{V}$-notch weir at the stream outlet of catchment. Weir flow rate was continuously monitored using the float-type water level instruments (C1: Steven Recorder Chart; C3: W-021, Yokogawa, Japan) and capacitive water level sensor (C1 and C3: WT-HR, TruTrack, NZ). The discharge was calculated using rating table for dischargestage relationships. Rainfalls were measured by a standard manual storage rain gauge and a tipping bucket rain gauge near the weirs. Automatic tipping bucket rain gauge by Ota Keiki Seisakusho (s/n 689012) with bucket capacity sensitivity of $0.5 \mathrm{~mm} /$ tip and receiver diameter is $200 \mathrm{~mm} \pm 0.3$. Rainfall events were defined as a rain amount captured $>0.5 \mathrm{~mm}$ with no periods of rainfall of more than 6 hours from the last rainfall events.

2.3. Analysis. The average daily discharges of years 1997,1998 , 1999, 2000, 2001, 2002, 2003, 2004, 2006, and 2007 were used to determine the water yields based on the water years in Malaysia which starts from July of each year to June in the following year. Water year, also known as hydrologic year, which is from 1 July to 30 June of the following year, is the period for the southern hemisphere. It is based on any twelve-month period, usually selected to begin and end during a relative dry season and used as a basis for processing streamflow and other hydrological data. The year from 1 July 2006 to 30 June 2007 is called the 2007 water year. 
TABLE 1: Catchment characteristics of $\mathrm{C} 1$ and $\mathrm{C} 3$.

\begin{tabular}{|c|c|c|}
\hline Element & $\mathrm{C} 1$ (undisturbed forest) & C3 (forest plantation) \\
\hline Size (ha) & 32.8 & 14.4 \\
\hline \multicolumn{3}{|l|}{ Elevation: (m.a.s.l) } \\
\hline Highest & 175 & 150 \\
\hline Lowest & 48 & 65 \\
\hline Mean slope (\%) & 32.5 & 27.7 \\
\hline Aspect & Northwestern & Southwestern \\
\hline Stream order & 3rd order & 2nd order \\
\hline Drainage density $\left(\mathrm{km} \mathrm{km}^{-2}\right)$ & 5.1 & 4.6 \\
\hline \multicolumn{3}{|l|}{ Morphology } \\
\hline Form factor & 0.51 & 0.50 \\
\hline Circulatory ratio & 0.71 & 0.58 \\
\hline Shape factor & 1.94 & 2.01 \\
\hline Elongation ratio & 0.81 & 0.80 \\
\hline Vegetation (main) & Koompassia malaccensis, Eugenia spp., Canarium spp. & Hopea odorata \\
\hline Soil series & $\begin{array}{c}\text { Kuala Berang } \\
\text { (Orthoxic Tropodult) } \\
\text { Bungor (Typic Paleudult) }\end{array}$ & $\begin{array}{c}\text { Kuala Berang } \\
\text { (Orthoxic Tropodult) }\end{array}$ \\
\hline Surficial geology & \multicolumn{2}{|c|}{ Metamorphic rocks (quartzite, quartz mica schist, graphitic schist, and phyllite from Arenaceous series) } \\
\hline
\end{tabular}

The hydrographs were separated using the method of Hewlett and Hibbert [18] into stormflow and delayed flow or baseflow for $\mathrm{C} 1$ and $\mathrm{C} 3$. The separation line has the constant slope of 0.0055 litres $\mathrm{sec}^{-1} \mathrm{ha}^{-1} \mathrm{hr}^{-1}$ which is projected from the initial rise until it intersects the recession limb of the hydrograph. Data from January 2006 to June 2007 were used for stormflow analysis as there were many storms of more than $30 \mathrm{~mm}$ that occurred in year 2006 and less in year 2007.

The selected single storm events were analysed based on the different rainfall characteristics and soil conditions. Antecedent precipitation index $\left(\mathrm{API}_{n}\right)$ is widely used as index to represent soil moisture condition with $n$ representing the number of days selected to be suitable for the index at the study site. It is defined as follows: $\mathrm{API}_{n}=\sum_{i=1}^{n} P_{i} / i$, where $P_{i}$ is daily precipitation ( $\mathrm{mm}$ ) and $i$ is days beforehand [19].

It is difficult to determine the time of concentration from the hydrograph. In the graph of storm events, $t_{c}$ was located at the point of recession limb where the change in the slope occurred. The kinetic wave equation used to determine the $t_{c}$ was as follows:

$$
t_{c}=\frac{0.93\left(L^{0.6}\right)\left(N^{0.6}\right)}{\left(i^{0.4}\right)\left(S^{0.3}\right)},
$$

where $L=$ overland flow length $(\mathrm{m}) ; N=$ Manning roughness; $i=$ rainfall intensity $\left(\mathrm{ms}^{-1}\right) ; S=$ average overland flow path slope $\left(\mathrm{mm}^{-1}\right)$.

The regression analysis of dummy variation was carried out to detect the changes in flows of the treated catchment (C3) by using the peak discharge parameter. The method used to compare regressions by the approach of dummy variables follows the multistep Chow test procedure. This technique was originally described by an economist [20] and then applied in hydrological research by Hewlett [21], Hewlett and Doss [22], Swindle and Douglass [23], and Hsia [24]. Multiple linear regression with dummy variables was applied to explain the relationship between $X$ and $Y$ at difference phases. Full model regression equation is as follows:

$$
\begin{aligned}
Y= & \alpha_{1}+\alpha_{2} D_{2}+\alpha_{3} D_{3}+\alpha_{4} D_{4} \\
& +\left(\beta_{1}+\beta_{2} D_{2}+\beta_{3} D_{3}+\beta_{4} D_{4}\right) X+e \\
= & \alpha_{1}+\alpha_{2} D_{2}+\alpha_{3} D_{3}+\alpha_{4} D_{4}+\beta_{1} X+\beta_{2} D_{2} X+\beta_{3} D_{3} X \\
& +\beta_{4} D_{4} X+e,
\end{aligned}
$$

where $Y$ is peak discharge of treated catchment (C3), $X$ is peak discharge of control catchment (C1),

$$
\begin{aligned}
& D_{2}= \begin{cases}1, & \text { for forest clear-cutting phase } \\
0, & \text { for other phases, }\end{cases} \\
& D_{3}= \begin{cases}1, & \text { for recovery phase } \\
0, & \text { for other phases, }\end{cases} \\
& D_{4}= \begin{cases}1, & \text { for postplanting phase } \\
0, & \text { for other phases, }\end{cases}
\end{aligned}
$$

and $\alpha_{i}$ and $\beta_{i}$ are parameters of regression model. 
TABLE 2: Yearly discharges (Q) and annual loss (ET) of C1 and C3 based on water year and by percentages of rainfall.

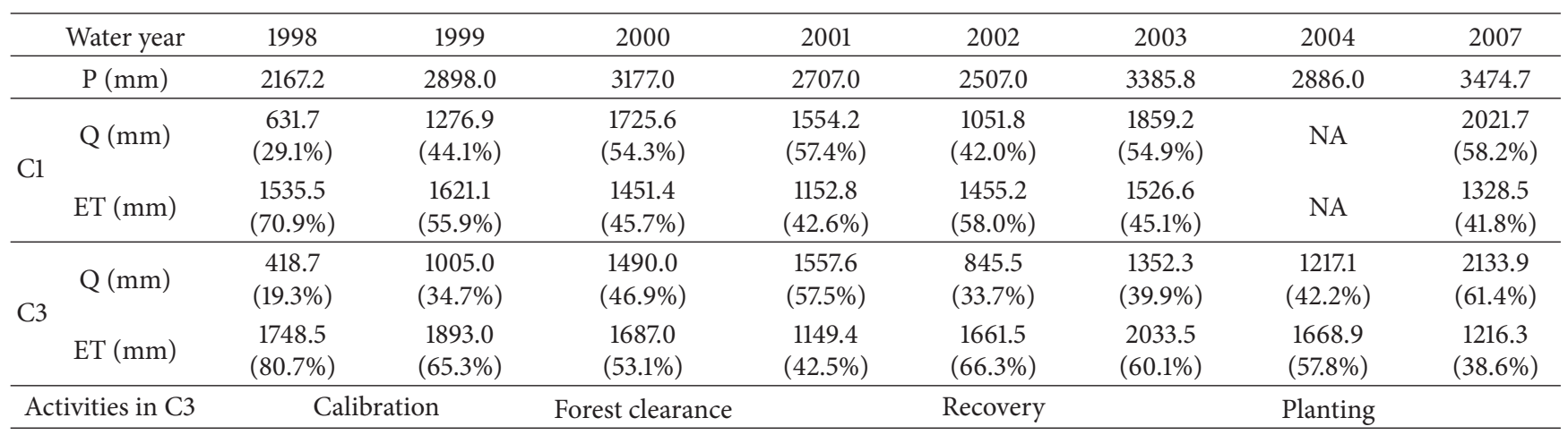

NA = not available.

Full model regression equation is as follows:

$$
\begin{aligned}
Y= & \alpha_{1}+\alpha_{2} D_{2}+\alpha_{3} D_{3}+\alpha_{4} D_{4} \\
& +\left(\beta_{1}+\beta_{2} D_{2}+\beta_{3} D_{3}+\beta_{4} D_{4}\right) X+e \\
= & \alpha_{1}+\alpha_{2} D_{2}+\alpha_{3} D_{3}+\alpha_{4} D_{4}+\beta_{1} X+\beta_{2} D_{2} X \\
& +\beta_{3} D_{3} X+\beta_{4} D_{4} X+e,
\end{aligned}
$$

where $\alpha_{1}$ is intercept before clear felling (Calibration), $\alpha_{2}$, $\alpha_{3}$, and $\alpha_{4}$ are differential intercepts, $\beta_{1}$ is slope coefficient before clear felling, and $\beta_{2}, \beta_{3}$, and $\beta_{4}$ are differential slope coefficients.

\section{Results and Discussion}

3.1. Water Yield Changes. Generally, Table 2 shows the discharges from the two small headwater catchments fluctuated according to the rainfall received in that particular year. The water yield of $\mathrm{C} 1$ was very low in 1998 water year which coincided with the extreme weather that occurred in the same year but it was increased the following 1999 water year with the increase in rainfall. The rainfall received was also low in 1998 water year compared with the long-term average $(2816 \mathrm{~mm})$. Discharges were higher than ET for undisturbed forest (C1) in 2001, 2003, and 2007 water years (except in 2002 water year).

The same situations also found in C3 in 1998 and 1999 water years with Q were less than ET. In the following year after forest clearance of C3, Q was more than ET but reduced to be lower from 2002 to 2004 water years and then became higher again in 2007 water year, that is, two years after tree planting. There were lacks of Q data for years 2004 and 2005 (C1) and year 2005 (C3). Hence, the water balances were not available for 2004, 2005 and 2006 water years (C1) and 2005 and 2006 water years (C3).

Meanwhile, it showed that the discharges amount was lower in C3 than in C1. This is related to the differences between the two catchments. $\mathrm{C} 1$ is bigger and has a higher stream order than C3. But in the 2007 water year, the water yield indicated that the discharge from C3 was higher than $\mathrm{C} 1$ after it had been cleared again in 2004 before planting and two years after the trees were planted. The difference was only $188 \mathrm{~mm}$ which is small compared with the yearly total, considering that the forest plantation was in the growing stage.

Based on the water balance analysis the water yields, Q ranged from $29.1-58.2 \%$ of $\mathrm{P},(\mathrm{C} 1)$ and $19.3-61.4 \%$ of $\mathrm{P}(\mathrm{C} 3)$, while the ET values ranged from $41.8-70.9 \%$ of $\mathrm{P}(\mathrm{C} 1)$ and 42.5-80.7 of P (C3). The high ET found in this study, suggest that humid tropical forest needs high energy to satisfy its evapotranspirative demands.

The impacts of forest plantation establishment depend on two major factors which are the clear felling operation and plant species characteristics. The site (C3) was clearcut and the use of heavy machinery during site preparation damaged the soil surface and increased the surface runoff. The construction on forest roads and skid trails in the forest logging operation in C3 also contributed quite a major portion of surface runoff to the stream. Earlier, study at C3 by Sidle et al. [25] found that the logging roads contribute more $Q$ to the stream than the skid trails. As the result, $78 \%$ of the soil loss from the road system (including log landings) was delivered to the stream in the 16 months after forest logging begun.

This finding concurred with Negishi et al. [26] who highlighted the importance of intercepted subsurface flow (ISSF) contribution to road runoff and sediment transport at C3. The area of C3 constituted 3.2\% of logging roads, $6.5 \%$ of skid trails, and $1.5 \%$ of log landing areas. The one year study revealed that $79 \%$ of the road runoff was contributed by the ISSF. The runoff came not only from vertical and lateral subsurface flow but also from preferential flow pathway in soil, including decayed and live root channel.

There was not much differences in water yield in $\mathrm{Cl}$. However, C3 showed significant increase in water yield after the forest was clear-cut and it took about three years before the values started to decline as the forest was recovering (Figure 2). As the $H$. odorata in C3 was still young (2 years old) the water yield in $\mathrm{C} 3$ was higher than $\mathrm{C} 1$ by $188 \mathrm{~mm}$.

The results from this study are consistent with the findings from small paired-watershed studies with an area of less than $100 \mathrm{~km}^{2}$. The annual runoff was found almost similar to the finding from other studies despite the difference in forest species, forestry operation, and climatic condition. This has been shown in the studies by Scott and Prinsloo [9] 


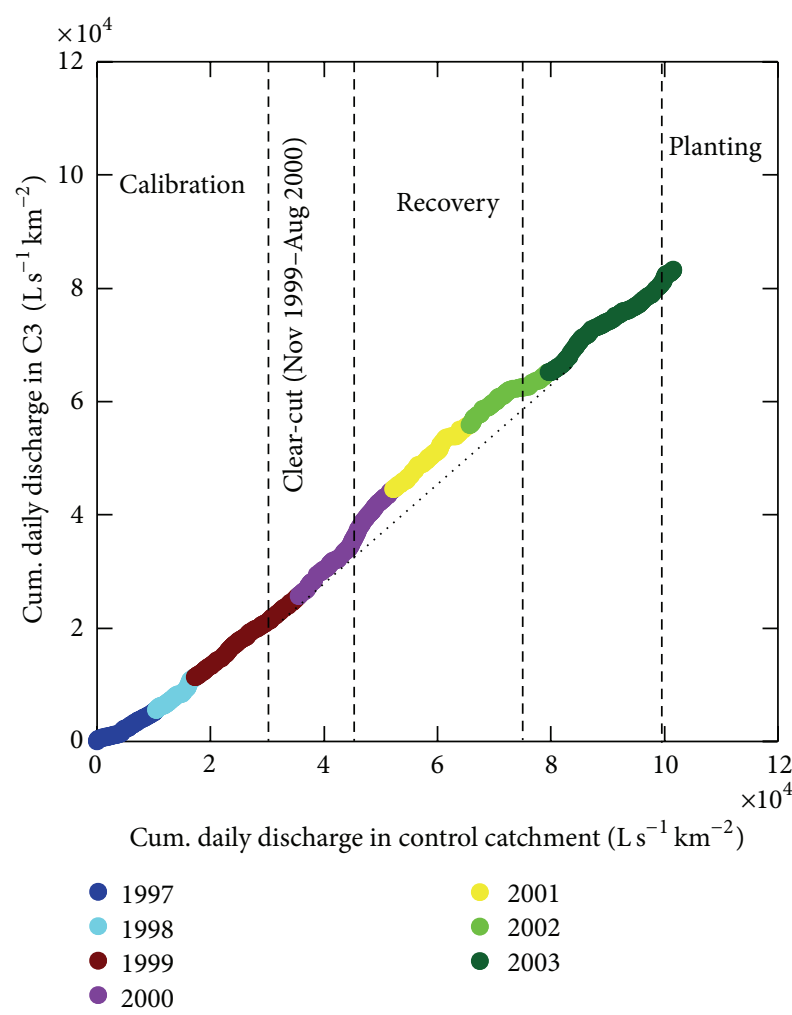

FIgURE 2: Changes in cumulative daily discharge between $\mathrm{Cl}$ and C3 which showed the effect of clear-cutting during the preparation of forest plantation in C3.

and Alila et al. [10]. The effects also were found in earlier studies by Bruijnzeel [27] and Waterloo et al. [28]. The greatest effect on discharge was observed during forest clearance and the recovery period begin for 2-3 years after planting has completed. The study of five small catchments by Webb et al. [29] showed a significant increase in streamflow following forest disturbance. For the catchment which was logged and burnt the annual runoff had returned to pretreatment levels within 2.5 years. The annual water yield changes range from 120 to $319.6 \mathrm{~mm}$.

The study on impacts of forest harvesting of a large watersheds $\left(>1000 \mathrm{~km}^{2}\right)$ which was conducted by Zhang et al. [30] at Yangtze River basin $\left(2528 \mathrm{~km}^{2}\right)$ showed that the significant annual runoff change occurred about 10 years after the intensive harvesting with the average in annual runoff increment being $38 \mathrm{~mm} \mathrm{yr}^{-1}$.

3.2. Stormflow Characteristics. Rainfall less than $30 \mathrm{~mm}$ (small storms) produced small stormflows and therefore the effect of antecedent soil moisture was not obvious. Under this condition, the bulk of stormflow was contributed by channel precipitation and direct runoff riparian areas. When the storm was more than $30 \mathrm{~mm}$, the stormflow produced was heavily governed by the soil moisture conditions which involved interflow/subsurface flow processes. Results from the hydrograph separation showed that the stormflow responses to storms can be clearly divided into wet and dry conditions. As suggested by Noguchi et al. [31], the relationships between rainfall and stormflow for storms more than $30 \mathrm{~mm}$ can be evaluated using linear regressions as shown in Figure 3 for $\mathrm{C} 1$ and $\mathrm{C} 3$, respectively.

The changes in the hydrologic response to forest clearing and subsequent planting of plantation species were detected by the relationships between stormflow and rainfall amount under wet and dry conditions. The stormflow response was closely related to the antecedent soil moisture conditions. With the smaller forest canopy, less rainfall was needed to start producing stormflow compared with a much denser forest during wet and dry conditions. With more vegetation covering the surface, the stormflow duration was longer with more time taken during the recession period.

The linear regression equations show that the stormflows started to increase when the rainfalls exceeded the threshold limits of $34.5 \mathrm{~mm}$ for $\mathrm{C} 1$ and $22.1 \mathrm{~mm}$ for $\mathrm{C} 3$ during wet conditions. The thresholds rainfall for stormflow production increased slightly during dry conditions to $53.1 \mathrm{~mm}$ for $\mathrm{C} 1$ and to $45.8 \mathrm{~mm}$ for $\mathrm{C} 3$, respectively. $\mathrm{C} 3$ responded faster than $\mathrm{C} 1$. Another event occurred between wet and dry conditions where large rainfall with low stormflow was determined and it was considered as transition between the two conditions. During rains that occurred following the dry conditions, water was absorbed quickly in the soil so that only small stormflows were produced even though the amounts of rainfall were large.

3.3. Stormflow Response to Rainfall Characteristics. The hyetograph and single peak storm hydrograph analysis demonstrate the quick responses of these two catchments with the stormflow (QF) duration and time of concentration $\left(t_{c}\right)$ were faster in $\mathrm{C} 3$ than in $\mathrm{C} 1$, while the times to peak $\left(t_{p}\right)$ were almost the same for both (Table 3 ). The rising limbs of the hydrographs for both catchments were very steep and the recession limbs depended on the rainfall intensity, especially during large storm events. This analysis used 21 single peak storm events both in $\mathrm{C} 1$ and $\mathrm{C} 3$. On average, $\mathrm{C} 1$ has a longer stormflow duration $(12.1 \mathrm{hr})$ compared with C3 $(7.0 \mathrm{hr})$. This is expected because the overland flow path length in $\mathrm{Cl}$ $(75.0 \mathrm{~m})$ is longer than in C3 $(13.9 \mathrm{~m})$. The estimated time of concentration $t_{c}$ in $\mathrm{C} 1$ was $24.7 \mathrm{~min}$, whereas for C3 it was only $13.8 \mathrm{~min}$. Although the maximum and minimum times to peak $t_{p}$ for $\mathrm{C} 1$ and $\mathrm{C} 3$ showed considerable differences, the average $t_{p}$ values for both catchments were very close.

The forest clearing resulted in C3 responded faster than in $\mathrm{C}$. The hydrograph shape with a steep rising limb and concave recession limb is quite typical to vegetated small catchments. For example, in the subhumid tropical forest of Karso watershed in India, with an annual rainfall of $1243 \mathrm{~mm}$, Rai et al. [32] found that the hydrograph response to rainfall varied with rainfall intensity and vegetation cover changes in rainfall-runoff responses as a result of natural forest conversion to forest plantation, especially during large storm events.

Besides the influence of vegetation cover on runoff generation, rainfall intensity also plays an important role in stormflow generation. For the same amount of storm size, 


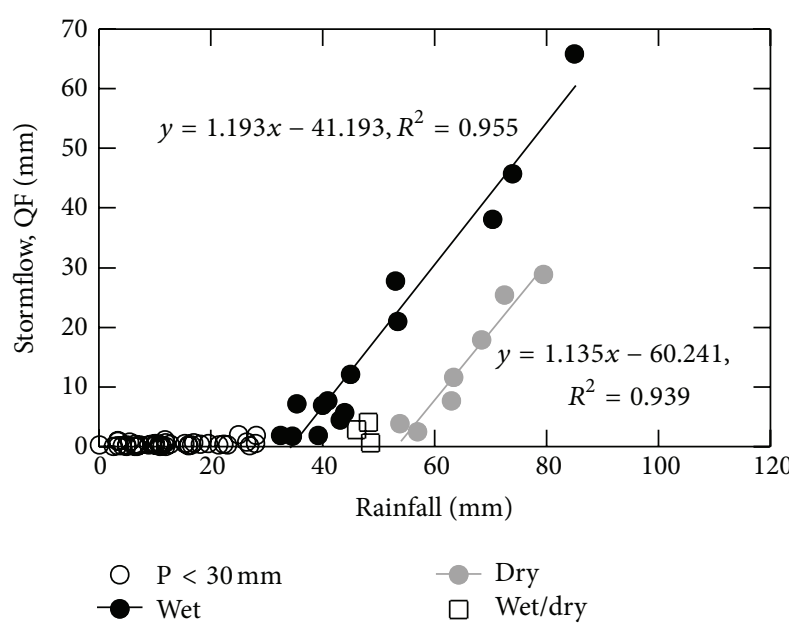

(a)

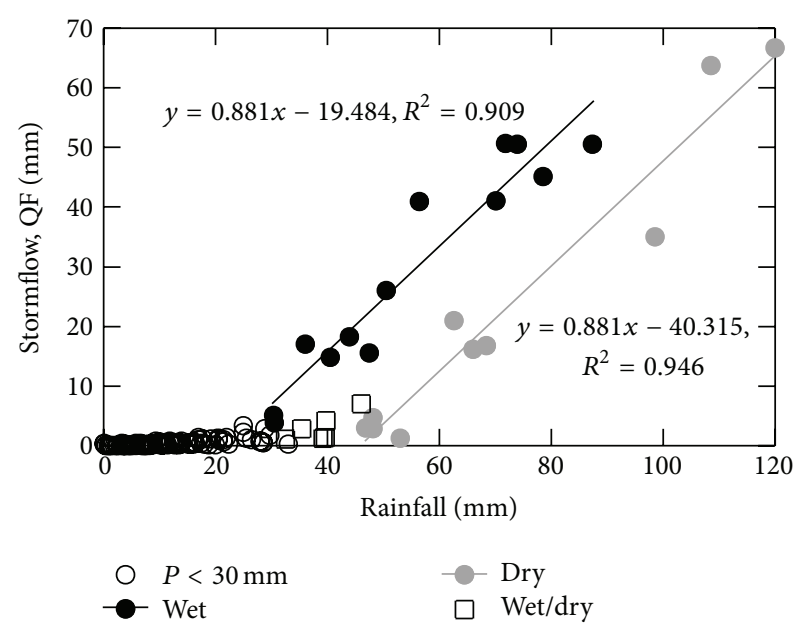

(b)

FIGURE 3: Relationships between stormflow (QF) and rainfall events during wet and dry conditions in control catchment C1 (a) and plantation catchment C3 (b) for observation from January 2006 to June 2007.

TABLE 3: Single peak hydrograph characteristics in C1 and C3 for 2007 water year. The parameters include time to peak $\left(t_{p}\right)$, quick flow $(\mathrm{QF})$ duration, and time of concentration $\left(t_{c}\right)$ with $n$ being the number of storms.

\begin{tabular}{lccccccccc}
\hline & \multicolumn{3}{c}{ Time to peak, $t_{p}(\mathrm{~min})$} & \multicolumn{3}{c}{ QF duration $(\mathrm{hr})$} & \multicolumn{3}{c}{ Time of concentration, $t_{c}(\mathrm{~min})$} \\
& Max & Min & Mean & Max & Min & Mean & Max & Min & Mean \\
\hline C1 $(n=25)$ & 42.0 & 6.0 & 28.5 & 35.0 & 1.4 & 10.9 & 47.0 & 10.5 & 24.0 \\
C3 $(n=33)$ & 54.0 & 12.0 & 27.4 & 23.7 & 1.5 & 6.2 & 28.1 & 8.4 & 14.1 \\
\hline
\end{tabular}

short storm duration (high intensity) produces more total discharge and also stormflow duration is shorter for less vegetated surface than matured forest canopy. The largest effect on the changes can be seen in the analysis of single peak storm events. The magnitude of peak discharge was higher and the QF duration was shorter in C3 than in C1. The increase in peak flow following forest clearing was also observed by Guillemette et al. [7] in Montmorency Forest in Quebec, Canada.

Figure 4(a) shows single peak storm hydrographs on 19 July 2006 for C1 and C3. The soil on 19 July 2006 was relatively dry because there had been no rain for seven days before that day and the $\mathrm{API}_{30}$ was $7.5 \mathrm{~mm}$ (less than $50 \mathrm{~mm}$ ). This rainfall was large with relatively long duration (60 min). The rainfall intensity was also high $\left(58.5 \mathrm{~mm} \mathrm{hr}^{-1}\right)$. The hydrograph rose six minutes earlier in $\mathrm{C} 3$ than in $\mathrm{C}$. The time taken during the recession (peak to end of separation line) for $\mathrm{C} 1$ was almost $1 \mathrm{hr}$ longer than for $\mathrm{C} 3$. However, the shapes of both hydrographs were almost similar. The hydrographs responded quickly and the recessions were also rapid with steep slopes. The relatively small rainfall of $28 \mathrm{~mm}$ on 15 October 2006 had a longer duration (50 min) as shown in Figure 4(b). There had been no rain for three days before that day and the $\mathrm{API}_{30}$ was $20.3 \mathrm{~mm}$ (less than $50 \mathrm{~mm}$ ). The resulted hydrograph of C3 was shaper with shorter time to peak compared with that of $\mathrm{C} 1$. The slope of the recession limb for $\mathrm{C} 3$ was also steeper with a shorter time to reach the end of separation from peak point compared with that of $\mathrm{C} 1$. The soil conditions were considered wet on 14 November and 8 December 2006 as the $\mathrm{API}_{30}$ were 89.5 and $54.4 \mathrm{~mm}$, respectively (more than $50 \mathrm{~mm}$ ). The longer duration $(48 \mathrm{~min})$ of a heavy storm $\left(58.1 \mathrm{~mm} \mathrm{hr}^{-1}\right)$ showed longer stormflow duration for both catchments on 14 November 2006. The gentle slope of the recession limb in $\mathrm{C} 1$ was in contrast to the sharp slope of a recession limb in C3 (Figure 4(c)). The stormflow shapes were not much different between Figures 4(c) and 4(d). Except during the light rain that occurred in short duration $(30 \mathrm{~min})$, the stormflow duration of $\mathrm{C} 1$ was longer than that of $\mathrm{C} 3$ on 8 December 2006, as shown in Figure 4(d). The flashy response and steep recession of stormflow in C3 were shown.

Noguchi et al. [33] described in detail the roles of soil moisture in rainfall-runoff response at $\mathrm{C} 1$. They found that saturation occurred at $10 \mathrm{~cm}$ depth near the river valley (30-50 $\mathrm{m}$ from the river bank) during wet conditions. They ascribed this to the presence of impeding layers at depths between 10 and $20 \mathrm{~cm}$ which contained high content of organic matter and high density of roots. This made the layers highly transmissive relative to the underlying soil layers. This showed that runoff generation in this catchment is associated with subsurface flow. The soil layer of Kuala Berang series at this depth consists of sandy loam to sandy loam with silt and numerous pores. Noguchi et al. [33] also found that, during dry condition, the streamflow responded quickly to rainfall and declined rapidly after the rain had stopped. This suggested that most of the net rainfalls were retained in the 

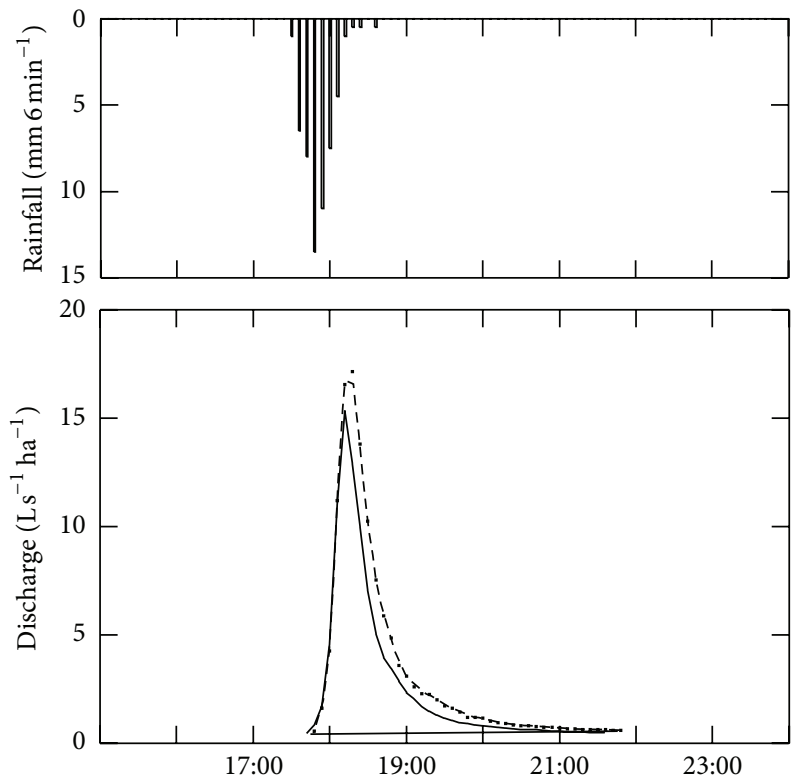

$\mathrm{Jul} / 19$

Date/time

(a)
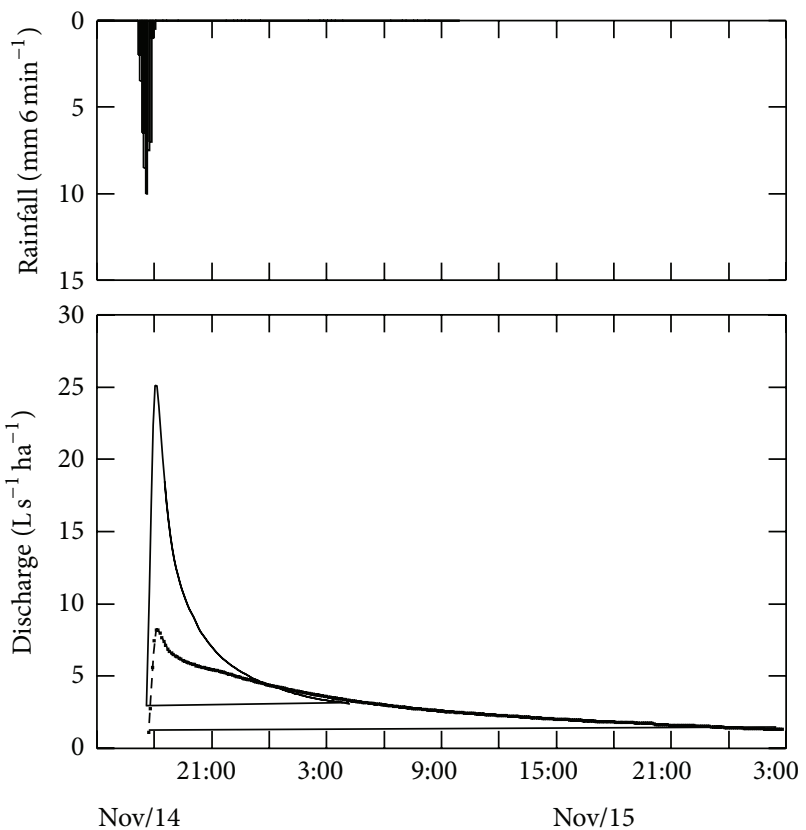

Date/time

-.. $\mathrm{C} 1$

$-\mathrm{C} 3$
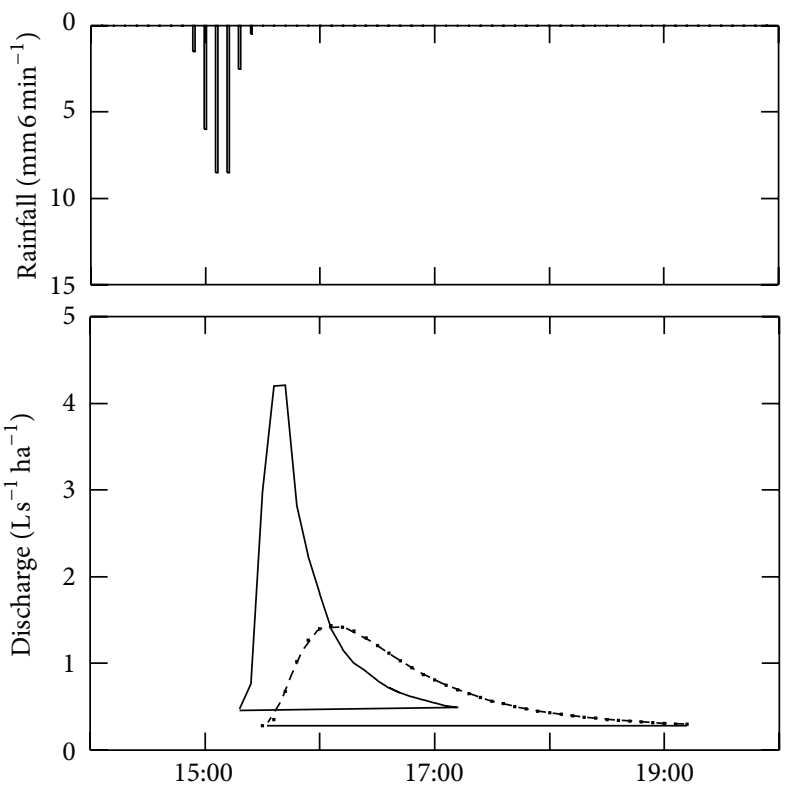

Oct $/ 15$

Date/time

(b)
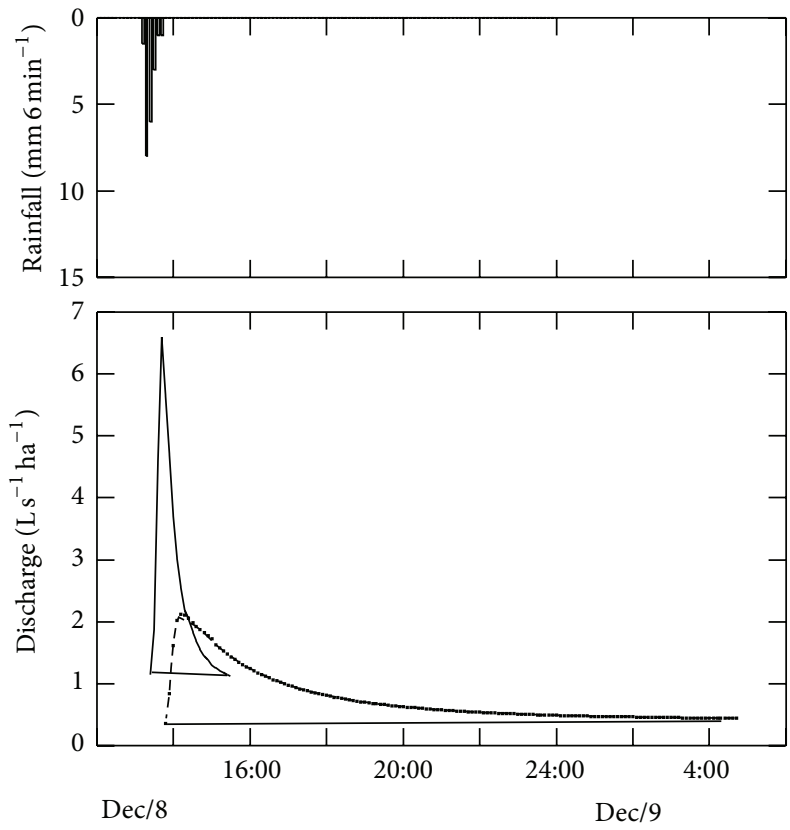

Date/time

$-\ldots \mathrm{C} 1$

$-\mathrm{C} 3$

(c)

(d)

FIgure 4: Stormflow hydrographs for C1 and C3 during (a) dry condition on 19 July 2006, (b) dry condition on 15 October 2006, (c) wet condition on 14 November 2006, and (d) wet condition on 8 December 2006.

soil to fill up the soil moisture deficit, and thus only a small portion could contribute to stormflow. During wet condition, the soil was wet at all parts of the slope and the rainwater was found to percolate to deeper parts and downslope as shown by the observations at $10 \mathrm{~cm}$ and $160 \mathrm{~cm}$ depths during large storms.
3.4. Regression Analysis on Dummy Variables for Logging Effects on Peak Discharge $\left(Q_{p}\right)$. Multiple linear regression with dummy variables was applied to explain the relationship between peak discharges of control catchment (C1); X and peak discharges of treated catchment (C3), $Y$, at difference phases. The peak discharges were determined from 
510 storms from years 1997 to 2007 from C1 and C3. By using Minitab, the results of multiple linear regressions with dummy variables could be written as

$$
\begin{aligned}
Y= & 0.043+2.15 D_{2}+2.21 D_{3}+6.03 D_{4}+1.37 X \\
& +1.40 D_{2} X-0.148 D_{3} X+0.182 D_{4} X+e .
\end{aligned}
$$

The results also show that not all of the parameters in the model are statistically significant at $5 \%$ level of significance. $D_{3}(P<0.05), D_{4}(P<0.001), X(P<0.001)$, and $D_{2} X(P<0.05)$ are statistically significant, but $D_{3} X(P=$ $0.641)$ and $D_{4} X(P=0.551)$ are not statistically significant. These results also show that the estimation process of the multiple linear regression model can be continued until the final multiple linear regression was determined (i.e., model with all parameters which are significant).

By using stepwise procedure, the results show that five predictors (independent variables) significantly influence the variable $Y$, that is, variable $X(P<0.001), D_{4}(P<0.001)$, $D_{2} X(P<0.001), D_{4} X(P<0.05)$, and $D_{3}(P<0.05)$ (in chronological order at stepwise results). In this final model, the constant (intercept) is not significant $(P=0.599)$, so we eliminate the constant from the model and reestimate the model without the constant. Therefore, the final multiple linear regression model could be written as follows:

$$
Y=2.11 D_{3}+6.07 D_{4}+1.26 X+2.02 D_{2} X+0.290 D_{4} X+e .
$$

This model shows that variable $X$ was significant with reference to variable $Y$ and the effects were different for each phase (Figure 5). The effect of $X$ on $Y$ at the forest clearcutting phase is the largest compared with other phases. The largest slope $(b)$ occurs at forest clear-cutting phase, that is, 3.28. It means that the increase of $X$ at this phase also yielded the largest increase of $Y$ compared with other phases, that is, 1.55 at the postplanting phase and 1.26 at both calibration and recovery phases. The peak discharges increased higher in $\mathrm{C} 3$ than $\mathrm{C} 1$ after the removal of forest canopy as the hydrograph response also showed the faster response and shorter stormflow duration in C3 with sharp rising limb and recession compared with $\mathrm{C} 1$ with comparatively less steep rising limb and longer stormflow duration with the effect of forest canopy cover. Additionally, the constant at the postplanting phase was the largest compared with other phases, that is, 6.07, 2.11, and 0 for the postplanting phase, recovery phase, and both forest clear-cutting and calibration phases, respectively. This shows that forest clearance changed the hydrological condition of the forested catchment with the effect to the peak discharge still existing years after the forest was planted and it would take time to go back to its original state with the forest recovery or it would not.

Further analysis of dummy regression showed the effect of forest clearing in increasing the peak discharge in C3 in relation to $\mathrm{C} 1$. The equation derived from the regression analysis on dummy variables showed the relationships between the control and treated catchments. These relationships can be used to predict water yield (peak discharge) that would occur in the treated catchment which can be applied to

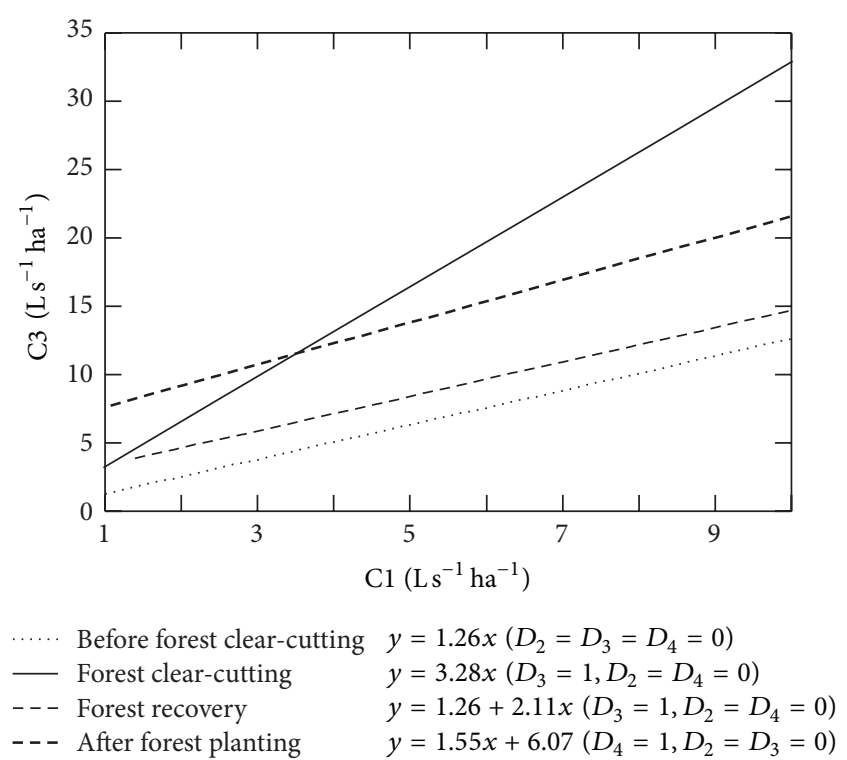

FIGURE 5: Multiple liner regressions analysis on peak discharge of $Q_{p}$ between treated catchment (C3) and control catchment (C1) after elimination of nonsignificant values in the analysis of dummy variables.

other treatment catchments at different sites. Four regression equations from the four stages were involved in the forest conversion that is calibration period, during forest clear-cut operation, forest recovery period, and postforest planting. The highest impact was shown during the forest clearance operation which showed that the peak flow increased about 3.3 times higher than control catchment, while the rate was higher for the postforest planting period as the area was cleared again prior to tree planting.

The colonization by undergrowth and natural vegetation expedites the hydrological recovery in the plantation catchment. There will be additional water yield for a few years while the Hopea odorata stands are still young and this would possibly decrease as the trees attain their full growth potential.

\section{Conclusions}

The influence of forest plantation establishment on discharge characteristics in a 14.4 ha area (C3) was conducted in this study. Based on the observation carried out for two years after the establishment of two-year-old H. odorata forest plantation and the analysis of unpublished monthly discharges data collection, four aspects of analysis were carried out. It was found that the total discharge in the young forest plantation was more than in the mature forested stand after two years of establishment. It means that the forest plantation establishment increased the streamflow. The yearly water yield indicated that the values in both catchments were fluctuated according to the rainfall received in the same year.

The stormflow responses to rainfall vary with soil moisture which is represented by antecedent precipitation index, incident rainfall, and initial flow. The responses can be clearly 
grouped into three conditions, namely,during wet condition, transitions from wet to dry conditions, and dry conditions. Strong linear regression relationships were shown between stormflow and rainfall events.

The response of stormflow in the young forest plantation (C3) to rainfall was faster than in $\mathrm{C} 1$, where less rainfall amount was needed for the stormflow thresholds for wet and dry conditions. The water reached the stream faster in C3 as the stormflow duration was shorter compared with $\mathrm{Cl}$. This shows that vegetation is one of the important factors in controlling runoff generation.

The greatest impact was observed during forest clearance. Increases in peak discharge and water yield even were still observed even after two years of forest planting.

This study has demonstrated the difference characteristics between forested and newly established forest plantation catchments. Forest plantation can be established with a close supervision in order to reduce the impact on the environment as the degree of disturbance determines how long the time needed for the forest to revert to its background level.

As a recommendation for the future research, detailed studies over longer time periods would be needed to show the changes with the growth of the trees. This will help uncover further characteristics of the H. odorata tree and its suitability as one of the tree species that can be planted in the forested catchment. This present study has provided some new and relevant information on the hydrological behaviour of forest plantation at Bukit Tarek Experimental Watershed which can be used in the forest management, particularly of this lowland rainforest.

\section{Conflict of Interests}

The authors declare that there is no conflict of interests regarding the publication of this paper.

\section{Acknowledgments}

The authors would like to thank Forest Research Institute Malaysia (FRIM) for facilitating this research; this study was financially supported by the Ministry of Science, Technology and Innovation (MOSTI) under the E-Science Fund (MOA) through Grant No. 31300203003. This study was also supported by the Japan Society for the Promotion of Science (JSPS) for KAKENHI (23221009).

\section{References}

[1] M. D. Newson, Land, Water and Development: Sustainable Management of River Basin System, Routledge, London, UK, 1997.

[2] R. C. Ward and M. Robinson, Principles of Hydrology, McGrawHill, London, UK, 2000.

[3] N. Abdul Rahim, "Water yield changes after forest conversion to agricultural landuse in Peninsular Malaysia," Journal of Tropical Forest Science, vol. 1, no. 1, pp. 67-84, 1988.

[4] N. Abdul Rahim and D. Harding, "Effect of selective logging methods on water yield and streamflow parameters in
Peninsular Malaysia," Journal of Tropical Forest Science, vol. 5, pp. 130-154, 1992.

[5] A. Malmer, "Water-yield changes after clear-felling tropical rainforest and establishment of forest plantation in Sabah, Malaysia," Journal of Hydrology, vol. 134, pp. 77-94, 1992.

[6] A. E. Brown, L. Zhang, T. A. McMahon, A. W. Western, and R. A. Vertessy, "A review of paired catchment studies for determining changes in water yield resulting from alterations in vegetation," Journal of Hydrology, vol. 310, no. 1-4, pp. 28-61, 2005.

[7] F. Guillemette, A. P. Plamondon, M. Prévost, and D. Lévesque, "Rainfall generated stormflow response to clearcutting a boreal forest: peak flow comparison with 50 world-wide basin studies," Journal of Hydrology, vol. 302, no. 1-4, pp. 137-153, 2005.

[8] C. Fernández, J. A. Vega, J. M. Gras, and T. Fonturbel, “Changes in water yield after a sequence of perturbations and forest management practices in an Eucalyptus globulus Labill. watershed in Northern Spain," Forest Ecology and Management, vol. 234, no. 1-3, pp. 275-281, 2006.

[9] D. F. Scott and F. W. Prinsloo, "Longer-term effects of pine and eucalypt plantations on streamflow," Water Resources Research, vol. 45, no. 7, Article ID W00A08, 2009.

[10] Y. Alila, P. K. Kuraś, M. Schnorbus, and R. Hudson, "Forests and floods: a new paradigm sheds light on age-old controversies," Water Resources Research, vol. 45, no. 8, Article ID W08416, 2009.

[11] H. P. Ganatsios, P. A. Tsioras, and T. Pavlidis, "Water yield changes as a result of silvicultural treatments in an oak ecosystem," Forest Ecology and Management, vol. 260, no. 8, pp. 13671374, 2010.

[12] J. Kinal and G. L. Stoneman, "Hydrological impact of two intensities of timber harvest and associated silviculture in the jarrah forest in south-western Australia," Journal of Hydrology, vol. 399, no. 1-2, pp. 108-120, 2011.

[13] B. X. Dung, T. Gomi, S. Miyata, R. C. Sidle, K. Kosugi, and Y. Onda, "Runoff responses to forest thinning at plot and catchment scales in a headwater catchment draining Japanese cypress forest," Journal of Hydrology, vol. 444-445, pp. 51-62, 2012.

[14] S. Noguchi, N. Rahim, S. Saifuddin, M. Tani, T. Sammori, and M. Tani, "Hydrological characteristics of tropical rain forest in peninsular Malaysia (1)-general hydrological observations on a hillslope," in Proceedings of the International Symposium on Forest Hydrology, Tokyo, Japan, October 1994.

[15] F. W. Roe, "The geology and mineral resources of the Fraser's hill area Selangor, Perak and Pahang, Federation Malaysia with an account of the mineral resources," Memoir No. 5, Geology Survey Department Federation of Malaya, 1951.

[16] S. Saifuddin, N. Abdul Rahim, and M. F. Abdul Rashid, "Establishment and physical characteristics of Bukit Tarek watershed," FRIM Research Pamphlet, vol. 110, pp. 1-51, 1991.

[17] S. Saifuddin, Hubungkait kiantara ciri-ciri morfometri dan sebahagian parameter hidrologi di tadahan berhutan, Tesis Ijazah Sarjana Sastera, Universiti Kebangsaan Malaysia, Bangi, Malaysia, 1994.

[18] J. D. Hewlett and A. R. Hibbert, "Factors affecting the response of small watersheds to precipitation in humid area. I," in Proceedings of the International Symposium on Forest Hydrology, W. E. Sopper and H. W. Lull, Eds., pp. 275-290, Pergamon Press, New York, NY, USA, 1967. 
[19] M. P. Mosley, "Subsurface flow velocities through selected forest soils, South Island, New Zealand," Journal of Hydrology, vol. 55, no. 1-4, pp. 65-92, 1982.

[20] D. Gujarati, "Use of dummy variable in testing for equality between sets of coefficients in two linear regression: a note," The American Statistician, vol. 24, no. 1, pp. 50-52, 1970.

[21] J. D. Hewlett, "Forests and floods in the light of recent investigation," in Proceedings of the Canadian Hydrology Symposium on Hydrological Processes of Forested Areas, New Brunswick, Canada, June 1982.

[22] J. D. Hewlett and R. Doss, "Forests, floods and erosion: a watershed experiment in the southeastern Piedmont.," Forest Science, vol. 30, no. 2, pp. 424-434, 1984.

[23] B. F. Swindel and J. E. Douglass, "Describing and testing nonlinear treatment effects in paired watershed experiments.", Forest Science, vol. 30, no. 2, pp. 305-313, 1984.

[24] Y.-J. Hsia, "Changes in storm hydrographs after clearcutting at a small hardwood-forested watershed in Central Taiwan," Forest Ecology and Management, vol. 20, no. 1-2, pp. 117-133, 1987.

[25] R. C. Sidle, S. Sasaki, M. Otsuki, S. Noguchi, and N. Abdul Rahim, "Sediment pathways in a tropical forest: effects of logging roads and skid trails," Hydrological Processes, vol. 18, no. 4, pp. 703-720, 2004.

[26] J. N. Negishi, R. C. Sidle, A. D. Ziegler, S. Noguchi, and N. A. Rahim, "Contribution of intercepted subsurface flow to road runoff and sediment transport in a logging-disturbed tropical catchment," Earth Surface Processes and Landforms, vol. 33, no. 8, pp. 1174-1191, 2008.

[27] L. A. Bruijnzeel, "Hydrological functions of tropical forests: not seeing the soil for the trees?" Agriculture, Ecosystems and Environment, vol. 104, no. 1, pp. 185-228, 2004.

[28] M. J. Waterloo, J. Schellekens, L. A. Bruijnzeel, and T. T. Rawaqa, "Changes in catchment runoff after harvesting and burning of a Pinus caribaea plantation in Viti Levu, Fiji," Forest Ecology and Management, vol. 251, no. 1-2, pp. 31-44, 2007.

[29] A. A. Webb, A. Kathuria, and L. Turner, "Longer-term changes in streamflow following logging and mixed species eucalypt forest regeneration: the Karuah experiment," Journal of Hydrology, vol. 464-465, pp. 412-422, 2012.

[30] M. Zhang, X. Wei, P. Sun, and S. Liu, "The effect of forest harvesting and climatic variability on runoff in a large watershed: The case study in the Upper Minjiang River of Yangtze River basin," Journal of Hydrology, vol. 464-465, pp. 1-11, 2012.

[31] S. Noguchi, N. Abdul Rahim, and M. Tani, "Runoff characteristics in a tropical rain forest catchment," Japan Agricultural Research Quarterly, vol. 39, no. 3, pp. 215-219, 2005.

[32] R. K. Rai, A. Upadhyay, and V. P. Singh, "Effect of variable roughness on runoff," Journal of Hydrology, vol. 382, no. 1-4, pp. 115-127, 2010.

[33] S. Noguchi, A. R. Nik, Z. Yusop, M. Tani, and T. Sammori, "Rainfall-runoff responses and roles of soil moisture variations to the response in tropical rain forest, Bukit Tarek, Peninsular Malaysia," Journal of Forest Research, vol. 2, no. 3, pp. 125-132, 1997. 

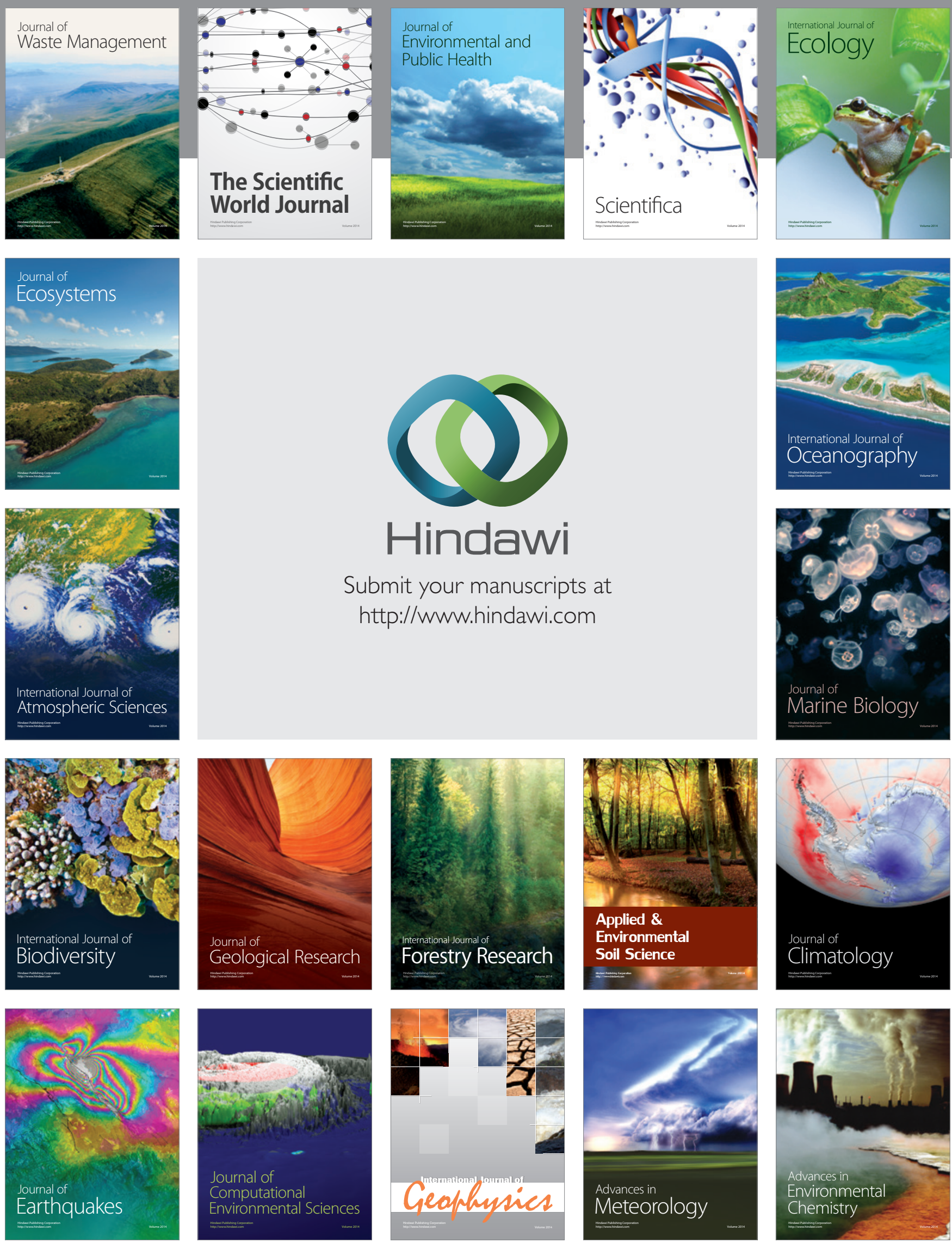